\title{
Effect of market age on production of goat meat and skin
}

\author{
MA Khatun ${ }^{1}$, MR Amin, ${ }^{1}$ MR Alam², MSI Khan ${ }^{1}$ \\ ${ }^{1}$ Department of Animal Science, Bangladesh Agricultural University, Mymensingh 2202, Bangladesh; ${ }^{2}$ School of \\ Sustainable Agriculture, University of Malaysia, Sabah, Malaysia
}

\begin{abstract}
The effect of marketing of goats at different ages on the yield of carcass and skin as well as economic impact were investigated. Landless and marginal farmers sold their goats 4 to 6 months earlier at 54 and 104\%, 3 and 5\%, 67 and 127\% less weight, dressing percentage and carcass yield, respectively less than small and medium farmers; and on average $36 \%$ less in small farmers than medium farmers. Estimated skin size of the goats belonged to landless and marginal farmers was $75 \%$ and $133 \%$ less than goats sold by small and medium farmers; and 33\% less in small farmers than medium farmers. An estimated goat slaughtered per year was 7.14, 5.44 and 4.28 million at the age of $6,10.5$ and 15.5 months, respectively and the yield of meat and skins was $23.28,31.99$ and 31.67 million $\mathrm{kg}$ and 10.71 , 15.46 and 14.98 million sqft, respectively. It is estimated that if goats are raised up to 15.5 months of age to higher weight of $17.10 \mathrm{~kg}$ may provide additional 41.08 million $\mathrm{kg}$ meat and 19.4 million sqft skins and their present market values would be Taka 14377 and 873 millions, respectively at the present subsistence level of goat farming and marketing systems in the country.
\end{abstract}

Key words: Goat, market age, meat, skin, economic impact

Bangladesh Animal Husbandry Association. All rights reserved.

Bang. J. Anim. Sci. 2013. 42 (1): 67-70

\section{I ntroduction}

Goats reared by different farm categories have an influence on goat production, marketing and their products in the country (Khatun et al. 2012). Marketing of farm product is usually depends on demand and supply in terms of quantity and quality of products but seldom considered when demand exceeds availability in the market. In this situation consumers evaluate and choose goods according to their preference and purchasing ability within the availability of product in the market (Alam 2007b). The scenario of goat meat market in Bangladesh is that the supply is far below of their demand. The consumers buy according to own preference and judge meat quality by own criteria of evaluation while buying fresh meat from butchers. This system of marketing channel often leads to misjudgment of quality goat meat and consequently, its price. The producers are also deprived of actual price of goat (Alam 2007a). Goat skin is considered high quality raw material for leather industry. A policy on market weight and age of slaughter may yield qualitative and quantitative leather, reduce the cost of tanning and higher value due to larger skin size. Policy is also required to generate good dividend in the market and economic return to the farmers. Presently, scanty information is available on the effect of indiscriminate marketing and slaughtering of goats on yield of meat and skins and their likely impact on economy. Therefore, an investigation is needed to formulate effective policies on rearing and marketing of goats for improving production, income of the owners as well as meet consumer's requirement. This study investigated the factors influencing selling of goats at different age and weight on their carcass and skin yield, economic contribution and potential of improvement through effective policies on goat rearing.

\section{Materials and Methods}

Market survey was conducted to determine the effects of selling of goats on yield of carcass and skin and its economic impact. Details of data collection and location from different categories of farmers and statistical analysis are reported in the previous publication (Khatun et al. 2012). Data on size of goat was estimated from height and length of goat by measuring with tape from top of shoulder to base of foot and from point of shoulder to point of hip, respectively. Dressing percentage of goats was estimated according to Singh and Sengar (1979) and Chowdhury and Faruque (2004). Size of skin was estimated on the basis of relationship between the age and skin size according to Table 1 and based on the rule followed at the Institute of leather Technology ( $\mathrm{J}$. Ahmed, personal communication). 

Khatun et al. (2013) Bang. J. Anim. Sci. 42 (1): 67- 70

Table 1. Skin size of goat on the basis of age

\begin{tabular}{lccccccccccc}
\hline Age (months) & 3 & 4 & 5 & 6 & 7 & 8 & 9 & 10 & 11 & 12 & 18 \\
\hline Skin size (sqft) & 0.75 & 1.00 & 1.25 & 1.50 & 1.75 & 2.00 & 2.25 & 2.50 & 2.75 & 3.00 & $3.50-4.00$ \\
\hline
\end{tabular}

Source: J Ahmed (personal communication)

The value of goat meat was estimated based on market price of Taka $350 / \mathrm{kg}$ and price of skin was calculated based on Taka 45/ sqft (BSCIC, 2002). Statistical analysis of the data was analyzed with the help of SPSS-V-16 computer package program.

\section{Results and Discussion}

\section{Effect of market age on meat and skin yield}

Apart from religious occasion most of the goats are sold throughout the year for meat from six months to eighteen months of age (Khatun et al. 2012), having different body conformation ranged from very emaciated to moderately fat and their price is based on visual observation of the goats at the time of marketing. The producers, mainly landless farmers raised and marketed goats to meet immediate family need and often sell goat in poor conformation. This type of goat was the major meat supplier in the market. On the other hand, medium farmers raised goat for cash income and sold at more matured age (15.5 months) and weight (17.10 kg) and consequently, demand for these goats was higher due to better body conformation and size (Khatun et al. 2012). Moreover, old does that were unable to breed were sold for meat. The farmers sold goats to the livestock market at negotiated price between the sellers and buyers on the basis of visual assessment of conformation and live weight. This system invariably might have underestimated the weight and value and consequently, the farmers were often paid less than market value. Landless and marginal farmers sold their goats 4 to 6 months earlier at 54 and $104 \%$ less weight than small and medium farmers (Table 2). Consequently, their estimated dressing percentage was differed by 3 to $5 \%$ but carcass yield was found 67 and $127 \%$ less compared to small and medium farmers; and on average $36 \%$ less in small farmers compared to medium farmers.

The average market weight and age of goats belonged to landless, marginal, small and medium categories of farmers were 8.39, 12.89, 17.10 and $17.20 \mathrm{~kg}$ and $6,10.5,15.5$ and more than 18 months of age, respectively, reported by Khatun et al., 2012. Estimated skin size of goats belonged to landless and marginal farmers was found 75 and $133 \%$ less compared to goats sold by small and medium farmers; and 33\% less in small farmers compared to medium farmers (Table 2). It is apparent that the quantity and quality of meat and skin production and financial return from these goats were significantly affected by owners of goat and their farming systems. In recent studies on this goat breed have shown that supplementation of concentrate feed and improved nutrition increased live weight and carcass yield (Moniruzzaman et. al. 2002; Shahjalal et al. 2000; Chowdhury and Faruque 2004). The medium farmers having ability of providing better feed and management to their goats were able to sell at higher live weight compared to resource-poor farmers. Chowdhury and Faruque (2004) have reported that these goats achieved highest meat production at 9 months of age by provision of balanced nutrition. Present findings suggest that goats in rural communities reached to this stage of meat production at 15.5 months of age which would have been achieved 6 months earlier by better feeding and management and quick turnover to investment that was almost similar with the study conducted by Alam (2007a).

\section{Potential of increasing meat and skin production}

In Bangladesh, 18.6 million goats are slaughtered per year according to the estimation made by FAO (2003). Estimated meat and skin production and their value per year was based on percent and number of goats marketed and live weight of goats at different ages (Khatun et al. 2012) and their estimated carcass weight are presented in Table 3. The data in Table 3 were extrapolated to estimate the potential increase of meat and skin production from goats belonged to 6 and 10.5 months of age by marketing at the age of 15.5 months and data are presented in Table 3. It appears that about 7.14 and 5.44 million goats were slaughtered per year at the age of 6 and 10.5 months, respectively. Meat and skin yield from these goats at 6 and 10.5 months of age were 23.28 and 31.99 million $\mathrm{kg}$ and 10.71 and 15.46 million sqft, respectively. Yield of meat and skin is expected to be higher at 15.5 months of age. Only 4.28 million goats of 15.5 months age 
was slaughtered per year and estimated meat and skin yield from these goats were about 31.67 million $\mathrm{kg}$ and $14.98 \mathrm{sqft}$, respectively. If the goats belonged to the above age groups were marketed at 15.5 months of age, then about 41.08 million $\mathrm{kg}$ of meat and 19.4 million sqft of skin (Table 4) would have been produced in the country in the existing goat farming and marketing systems.

\section{Prospect of improving productivity of goats}

It is evident from this study that if goats are reared up to potential market demand for age and weight, quantity and quality of meat and skin would have been higher in the prevailing farming systems. Majority of the goat farmers in the country are either landless or marginal, and therefore are the large contributors of goat meat and skin in the market.

They sell goats at $79 \%$ less live weight than the market preference for goats of $15 \mathrm{~kg}$ live weight. If these goats are raised and marketed according to consumers preference, about 41.08 million $\mathrm{Kg}$ and 19.4 million sqft of additional meat and skins of higher quality per year, respectively may be produced (Table 4) in existing crop-livestock farming system.

Table 2. Estimated average live weight and carcass weight of different ages of goats

\begin{tabular}{lcccccccc}
\hline $\begin{array}{l}\text { Farmer } \\
\text { categories }\end{array}$ & $\begin{array}{c}\text { Market } \\
\text { age } \\
(\mathrm{month})\end{array}$ & $\begin{array}{c}\text { Live } \\
\text { weight } \\
(\mathrm{kg})\end{array}$ & $\begin{array}{l}\text { Difference } \\
\text { in live weight } \\
(\mathrm{kg})^{*}\end{array}$ & $\begin{array}{c}\text { Dressing } \\
\text { percentage }\end{array}$ & $\begin{array}{c}\text { Carcass } \\
\text { weight } \\
(\mathrm{kg})\end{array}$ & $\begin{array}{c}\text { Difference } \\
\text { in meat } \\
\text { yield }(\mathrm{kg})^{*}\end{array}$ & $\begin{array}{c}\text { Skin } \\
\text { Size } \\
(\mathrm{sqft})\end{array}$ & $\begin{array}{c}\text { Difference } \\
\text { in skin yield } \\
(\mathrm{sqft})\end{array}$ \\
\hline Landless & 6 & 8.39 & - & 38.9 & 3.26 & - & 1.50 & - \\
\hline Marginal & 10.5 & 12.89 & $\begin{array}{c}4.50 \\
(54)\end{array}$ & 41.25 & 5.44 & $\begin{array}{c}2.18 \\
(67)\end{array}$ & 2.63 & $\begin{array}{c}1.13 \\
(75)\end{array}$ \\
\hline Small & 15.5 & 17.10 & $\begin{array}{c}8.71 \\
(104)\end{array}$ & 42.5 & 7.40 & 4.14 & 3.50 & $\begin{array}{c}2.00 \\
(133)\end{array}$ \\
\hline Medium & $>18$ & 17.20 & $\begin{array}{c}8.81 \\
(105)\end{array}$ & 43.25 & 7.57 & 4.31 & 4.00 & 2.50 \\
\hline
\end{tabular}

*Differences are shown to compare between 6 months with rest of the market age groups; +Values within bracket indicate percent difference

Table 3. Estimated meat and skin production per year

\begin{tabular}{|c|c|c|c|c|c|c|c|c|}
\hline $\begin{array}{l}\text { Market } \\
\text { age } \\
\text { (months) }\end{array}$ & $\begin{array}{l}\text { No. goats } \\
\text { slaughtered } \\
\text { per year } \\
\text { (million) }\end{array}$ & $\begin{array}{c}\% \text { goat } \\
\text { slaughtered } \\
( \pm S E)\end{array}$ & $\begin{array}{c}\text { Carcass } \\
\text { weight } \\
(\mathrm{kg} / \\
\text { head })\end{array}$ & $\begin{array}{c}\text { Meat } \\
\text { yield } \\
\text { (million } \\
\mathrm{Kg})\end{array}$ & $\begin{array}{l}\text { Skin } \\
\text { size/ } \\
\text { piece } \\
\text { (sqft) }\end{array}$ & $\begin{array}{l}\text { Skin } \\
\text { size } \\
\text { (million } \\
\text { sqft) }\end{array}$ & $\begin{array}{l}\text { Value of } \\
\text { meat }^{*} \\
\text { (million } \\
\text { Taka) }\end{array}$ & $\begin{array}{l}\text { Value of } \\
\text { raw skin } \\
\text { (million } \\
\text { Taka) }\end{array}$ \\
\hline 6 & 7.14 & $38.36 \pm 13.06$ & 3.26 & 23.28 & 1.50 & 10.71 & 8148 & 481.95 \\
\hline 10.5 & 5.88 & $31.60 \pm 4.26$ & 5.44 & 31.99 & 2.63 & 15.46 & 11196.5 & 695.7 \\
\hline 15.5 & 4.28 & $23.02 \pm 9.37$ & 7.40 & 31.67 & 3.50 & 14.98 & 11084.5 & 674.1 \\
\hline \multirow[t]{2}{*}{$>18$} & 1.31 & $7.03 \pm 1.51$ & 7.57 & 9.92 & 4.00 & 5.24 & 3472 & 235.8 \\
\hline & & \multicolumn{2}{|c|}{ Total production } & 96.79 & & 46.39 & 33901 & 2087.5 \\
\hline
\end{tabular}

SE, standard error of mean; *Based on market price of Taka 350/kg meat; \# Taka 45/sqft skin (BSCIC, 2002)

Table 4. Predicted goat meat and skin production and their market values

\begin{tabular}{|c|c|c|c|c|}
\hline \multirow{2}{*}{ Parameters } & \multicolumn{2}{|c|}{$\begin{array}{c}\text { Yield of goats sold at } 6 \text { and } \\
10.5 \text { months of age }\end{array}$} & \multirow{2}{*}{$\begin{array}{c}\text { Predicted yield } \\
\text { of goats if sold } \\
\text { at } 15.5 \text { months } \\
\text { of age }\end{array}$} & \multirow{2}{*}{$\begin{array}{c}\text { Predicted } \\
\text { additional } \\
\text { production and } \\
\text { market values }\end{array}$} \\
\hline & 6 months & 10.5 months & & \\
\hline No. goats slaughtered per year (millions) & 7.14 & 5.88 & 13.02 & \\
\hline Carcass weight $(\mathrm{kg} / \mathrm{head})$ & 3.26 & 5.44 & 7.40 & \\
\hline Meat production (millions kg) & 23.28 & 31.99 & 96.35 & 41.08 \\
\hline Value of meat (millions Taka) & 8148 & 11197 & 33722 & 14377 \\
\hline Skin size per piece (sqft) & 1.50 & 2.63 & 3.50 & \\
\hline Total skin production (millions sqft) & 10.71 & 15.46 & 45.57 & 19.4 \\
\hline Value of skin (millions Taka) & 482 & 696 & 2051 & 873 \\
\hline
\end{tabular}


Improvement of rearing and marketing systems would generate $55 \%$ more income from goats to subsistence farmers and contribute Taka 14377 and 873 million per year from meat and skin, respectively from goat farming alone. One of the leather exporters in the country, MB Rahman (personal communication) opinioned that skin from under aged goats is small and is used only for a pair of gloves and shoes and consequently, export value is less. Goats of at least one year old produce large skin with well-developed collagen fibres and can be used for more finished products. Black Bengal goat skin has higher demand for the manufacture of shoe for Ballet dancer and suggested to exert rules with incentives for marketing of goats at higher age and weight. Leather from undersized and more than one year old goats are exported at 1.00 and 1.5 dollars/ sqft, respectively (Prothom Alo, 1st April 2010). Taking these values the export of leather produced from goats aged $6,10.5$ months and 15.5 months would be 26.17 and 68.36 million dollars, respectively and additional foreign currency of 42.19 million dollars would have been earned (Table 3).

Goat rearing is considered an essential component of livestock farming for income generation and play vital role in improving livelihood of the resource-poor farmers in Bangladesh. Effective policies and facilities for goat farming are needed to overcome their farming constraints. A major requirement for acceptance of improved rearing practice by farmers is that they receive sufficient benefit and improvement plan must ensure that the benefits are economically viable. This requires concerted effort by the Government and NGO's for providing subsidy and soft loan for small scale goat entrepreneurship, improvement of marketing system, setting of cooperative feed mills and development of community-based disease prevention systems. Government is providing subsidy to fertilizers and irrigation for cereal crop production and cash incentive to the fishermen for prevention of catching "Jatka- Hilsha" fish of less than 6 inches in size to grow higher sizes and weights. If these types of incentives are provided to the goat owners to rear under appropriate husbandry system and market at higher live weight, goat would significantly contribute income to the owner and country's economy. Further studies are needed to investigate the effects of the above mentioned inputs on improvement of goat production systems, their productivity and income generation in existing farming systems.

\section{Conclusion}

It is concluded that raising of goats to higher weight of $17.10 \mathrm{~kg}$ and 15.5 months of age may provide additional 41.08 million $\mathrm{kg}$ meat and 19.4 million sqft skins and their estimated present market price is Taka 14377 and 873 million, respectively in the present subsistence level of goat farming.

\section{References}

Alam MR (2007a). Influence of farming systems on goat production, carcass quality and economic contribution to farmers in Bangladesh. In: The Quality of Goat Products (Eds R. Rubino and L. Sepe) Proceedings of the 25th International Goat Symposium, 24-26 May, Bella-Moliterno, Italy. P. 105-108.

Alam MR (2007b). Market perception on quality meat in Bangladesh. In: The Quality of Goat Products (Eds R. Rubino and L. Sepe) Proceedings of the 25th International Goat Symposium, 24-26 May, Bella-Moliterno, Italy. P. 73-76.

BSCIC (Bangladesh Small and Cottage Industries Corporation) (2002). An observation Report: 23.

Chowdhury SA, Faruque S (2004). Meat production characteristics of Black Bengal goat. Asian-Australian Journal of Animal Science. 17: 848-856.

FAO (Food and Agricultural Organization) (2003). Production Year Book. Rome, I taly.

Khatun MA, Alam MR, Amin MR, Khan MSI (2012). Marketing of goat at different age and weight by different categories of farmers in selected areas of Bangladesh. Bangladesh J ournal of Animal Science, 41: 55-59.

Moniruzzaman M, Hashem MA, Akhter S, Hossain MM (2002). Effect of different feeding systems on carcass and non-carcass parameters of Black Bengal goat. AsianAustralasian Journal of Animal Sciences, 15:61-65.

Shahjalal M, Bishwas MAA, Tareque AMM, Dohi H (2000). Growth and carcass characteristics of goats given diets varying protein concentration and feeding level. AsianAustralasian J ournal of Animal Sciences, 13: 613-618.

Singh SN, Sengar OPS (1979). Studies on the combining ability of desirable characteristics of important goat breeds for milk and meat separately and combination. A report of the PL-480 project on goats. Raja Balwant Singh College, Department of Animal Husbandry and Dairying, Bichpuri-283105 (Agra), UP, India. 